\title{
H2BC19P wt Allele
}

National Cancer Institute

\section{Source}

National Cancer Institute. H2BC19P wt Allele. NCI Thesaurus. Code C162793.

Human H2BC19P wild-type allele is located in the vicinity of $1 \mathrm{q} 21.2$ and is approximately $4 \mathrm{~kb}$ in length. This allele, which encodes putative histone H2B type 2-D protein, may play a role in nucleosomal structure. 